\title{
BASIC DETERMINANTS OF PRODUCING A MODERN TEXTBOOK
}

\author{
Adnan Tufekčić, PhD \\ Department of Pedagogy and Psychology \\ Faculty of Philosophy, \\ University of Tuzla (Bosnia and Herzegovina) \\ e-mail: $\underline{\text { adnan.tufekcic@untz.ba }}$
}

\begin{abstract}
S u m m ary
Making and using high quality textbooks is one of the most important aspects of an education system. Textbooks are one of the main teaching aids and entail a number of key requirements that must be met in the course of their drafting and design. With this regard, the article will analyse the basic pedagogical determinants of production and utilisation of the textbook in modern pedagogicaleducational reality. It will, in particular, deal with the extent to which a textbook is defined by the relevant curricula, and the extent to which the teleological function of textbooks is achieved by means of didactic, graphic design and technical, linguistic and health-hygienic formatting. It will also briefly touch upon the role of textbooks in the teacher's choice of a teaching method and structure of classes in the context of contemporary approaches to the educational process.
\end{abstract}

Key terms: textbook, modern classes, didactic format, graphic design format, linguistic format, health-hygienic format, teacher

\section{Introduction}

One of the most important issues pertinent to the design of a modern pedagogical-educational system is the production and use of high quality textbooks. ${ }^{1}$ In the contemporary, rapidly changing world, the role of textbooks in the context of presenting and disseminating the needed knowledge becomes more apparent than

\footnotetext{
${ }^{1}$ As part of the $\mathrm{BiH}$ pedagogical-educational reality, we may witness irresponsible and often superficial approaches to the process of textbook design. The majority of the "approved textbooks" are hardly deserving of the title as they would not pass either a scientific or a professional evaluation. Most of those "textbooks" are obviously not made to serve as one of the primary teaching aids but merely seen as a mass-consumption, sellable product. The basic requirements to be met in the process of designing a textbook are not taken into account at all. Furthermore, the requirements are not even discussed any longer, and this presents one of the main problems in the functioning of the educational system at all levels. The issue of the textbook review, as part of the overall problem, deserves special attention.
} 
ever. A textbook is "a book in which different scientific and professional contents are relayed to the user by means of a specially formatted didactic instrument, concurrent to the objectives of the education process, psychophysical maturity of students it is intended for, and unique requirements of the course and course curricula, i.e. school or level of education" (Potkonjak, Šimleša, 1989: 472). With the appearance of the so-called mass education, textbooks became the main teaching aid. Regardless of all the changes and education reforms, textbooks are still a mandatory source of knowledge in the teaching process. The fact that textbooks are irreplaceable leads to the conclusion that successful teaching would be impossible without high quality textbooks. Hence, textbooks remain, "mass, main and mandatory school books“"(Potkonjak, Šimleša, 1989: 472).

Contemporary social education controversies pertinent to vast tensions defining the twenty-first century education give a new dimension to the importance and function of the recent textbooks. One of the tensions is that between mass "production of knowledge" on one hand, and human ability to absorb and process the knowledge on the other. ${ }^{2}$ In addition to this, one of the basic paradigms of production of modern day textbooks is to take into account the new roles of teachers, who are progressively becoming "directors of the course, organisers, coordinators, professional guides, mentors" (Stevanović, 1998: 265).

All in all, textbooks as "mandatory textual teaching aids" (Vilotijević, 2001: 420) remain one of the main sources of knowledge in the learning process, provided that the principles and methods of their production and use for modelling a modern course are constantly reassessed. Time and again, the reassessment brings into question the pedagogical determinants of making and use of textbooks which by no means is a novel query, but is growing to be more and more prominent in the context of restructuring of the educational systems. Hence, the following sections of this article, without any illusion that something new can be said on the subject, will list, or rather remind of those basic determinants particular contemporary textbook authors depart from for some inexplicable reason.

\section{Pedagogical determinants of producing a textbook for the needs of modern education}

Should one wish to underline the distinction between textbooks and all other schoolbooks, one would resort to, conditionally speaking, main components of differentiation of classes from other parts of the pedagogical-education process. Classes are special in that they are:

1. Based on curricula;

2. Goal-oriented and of limited duration;

\footnotetext{
${ }^{2}$ For details on the tensions refer to: Delors, J. et all. (1998) Učenje: blago u nama izviješće UNESCO-u Međunarodnog povjerenstva za razvoj obrazovanja za 21. stoljeće (Learning: The Treasure Within - Report to UNESCO of the International Commission on Education for the Twenty-first Century), Zagreb: Educa.
} 
3. Managed and led by a teacher.

The basic pedagogical requirements for drafting a textbook are determined concurrently, as explained in detail below.

1. From the perspective of pedagogical and didactic discourse, the issue of the textbook design is necessarily and inseparably connected with the issue of course curricula, for textbooks are, as a rule, made and modelled in accordance with the curriculum for particular domains of teaching or for courses for particular types of schools. Therefore, one could say that the design and production of textbooks is always curricula-based. In a didactic sense, textbooks must reflect all the characteristics of curricula for particular courses and for particular levels of schooling. The characteristics include:

- Type of allocation of a course content foreseen by the curriculum (linear, concentric, spiral and combined allocation of a course content);

- Allocation of a course content by stages of the teaching process (domain of teaching, teaching topic, teaching unit);

- Extent and intensity of a course content (psychophysical capacities of students the textbook is intended for);

- Correlation to the content of other courses and teaching domains (vertical and horizontal correlation between all textbooks in particular types and levels of schools).

2. Given that textbooks are one of the permanent sources of knowledge in the teaching process, they must also entail a teleological dimension, i.e. they have to be created as to meet objectives, goals and purpose of teaching in the relevant course. The objectives may be classified, conditionally, in three groups: pedagogical, educational and functional. Everything that in the pedagogical-educationalfunctional terms should be achieved pertinent to the students in a particular domain of teaching or a course must be reflected in the course textbook. "Scientific, logicalmethodological, conceptual-semantic, didactic-method and other values a textbook may contain are in the closest possible correlation with the actual results of the course. However, the values themselves are never a sufficient guarantee that the particular goals and objectives of the teaching process will indeed be met" (Slatina, 1998: 137). The goals and results of a course will be achieved if the process of producing the relevant textbook meets the following requirements: ${ }^{3}$

\section{- Appropriate didactic formatting of a textbook}

This is the main requirement of the process of producing a textbook, for the didactic apparatus of a textbook is exactly what makes the textbook, "an object of the student's daily interest“ (Potkonjak, Šmleša, 1989: 472). Didactic design of a textbook is based on the:

\footnotetext{
${ }^{3}$ For details refer to: Vilotijević, M. (2001) Didaktika 3, (Didactics 3) Sarajevo: BH most, pg. $420-422$.
} 
- Basic principles of the teaching process and the principles of confluent education (principle of self-activism and spontaneity, principle of interaction and communication, principle of actualisation and totality); ${ }^{4}$

- Didactic values and principles (principle of age-appropriateness, principle of systemisation and gradualisation, principle of evidence, principle of rationalisation, principle of individualisation);

- Learning processes at different stages of development (analysis and synthesis, abstraction and generalisation, induction and deduction, systematisation and classification);

- Values and principles of learning and teaching in courses (mandatory interconnectivity of learning and teaching, learning by observing, researching and discovering, principle of active learning);

- Stages of a lesson (introduction, realisation, confirmation of knowledge, exercise, repetition and assessment).

At this, one should bear in mind that textbooks are not the only teaching aid in the modern education process and that, consequently, the didactic formatting of a textbook should also abide by the principle of the didactic-methodical complementation of the textbook with all other teaching aids. "Only in this complementary relationship amongst different sources of knowledge could a textbook fulfil its authentic pedagogical-educational functions. Therefore, the value of a textbook does not lay only in the textbook itself" (Slatina, 1998: 137). It is exactly this feature of textbooks to refer a student to other sources of knowledge and encourage him/her to take an active approach to his/her studies thus integrating all available sources of knowledge that is a key feature any textbook must possess in a modern information society. In this light, one should underline the particular importance of the textbooks aimed to prepare students for e-learning within education institutions, as well as for the so-called distance learning.

\section{- Appropriate graphic design and technical format of a textbook}

Graphic design and technical formatting of a textbook imply that the very appearance of the textbook should be made so to inspire curiosity, inquisitiveness and motivation in students involved in the course, as well as to have the textbook be useful and befitting the age of the students. Proper illustration is one of the key factors having the students accept/reject a textbook. The illustrations should additionally enrich the textual parts of a textbook, which is only possible when they are designed to emphasise something and not inserted just for the sake of being there.

${ }^{4}$ For details on education as a confluent process and the principles of confluent education refer to: Slatina, M. (2005) Od individue do ličnosti-uvođenje u teoriju konfluentnog obrazovanja (From A Person to A Personality - Introduction to The Theory of Confluent Education), Zenica: Dom štampe. 
Poor artistic and technical design and age-inappropriate graphics can result in a textbook failing to meet the relevant aesthetic requirements. Concurrently, "a textbook should not be only textual, intermittent by thematic titles, from cover to cover, because students, and younger students in particular, will not find it appealing. A textbook must contain illustrations - drawings, pictures, charts connected to the meaning of the text. The illustrations may be black and white or in colour, especially the textbooks intended for younger students. The titles and subheadings should be evenly distributed and nicely formatted. The paper quality must meet the textbook appropriate standards, the covers be tastefully designed to attract the students. Finally, a textbook should not be massive for this would only put off the students". (Vilotijević, 2001: 421). Technical format of a textbook also depends on whether the textbook is comprehensive (integrated), workbook or a socalled set. Integrated textbooks encompass all contents foreseen by the relevant course curriculum, workbooks refer to different exercise books, while a set includes several books (the reader, workbooks, practicum, etc.) covering the course curriculum.

Finally, one should underline that a modern textbook must also include different "additional" aids enriching its content, didactic-methodical, but also graphic-artistic dimension of the textbook. This primarily refers to the aids such as CDs and DVDs especially designed to both quantitatively and qualitatively complement the main textbook (multimedia approach to textbook design). The use of a textbook also entails active (creative) use of all such accompanying aids.

\section{- Appropriate linguistic format of a textbook}

Textbooks are one of the most important media for dissemination of knowledge. For this reason, the linguistic format of textbooks is one of the most sensitive issues, with the linguistic appropriateness for particular student age and the composition of textual and illustrated segments as its most important and most complex aspects. "The choice of language used in a textbook is gradually becoming the most important criteria of its informative value because language serves to relay an information, language is the link to the user, and should this 'speech community' (also referred to as the 'communication community') comprising a textbook and its user face an 'error' ('communication glitch'), the communication will not be possible and the very purpose of the textbook as a source of knowledge will become disputable“ (Potkonjak, Šimleša, 1989: 473). Hence, the process of drafting a textbook should involve creative participation of linguistic experts and not only in terms of proofreading of the final text but as collaborative effort with the authors in deciding on the adequate textbook wording (based on the age of the students, curriculum, etc.). This is of utter importance as the students are learning the words of specialised science and art registers based on what is used in their textbooks. Therefore, a proper linguistic formatting of textbooks enables a special link between scientific principles and suitability for the age of students in the teaching process. 


\section{- Appropriate health-hygienic format of a textbook}

Textbooks are the teaching aids students are in daily and permanent contact with, which is why the health of the students should be of concern in the process of producing a textbook. Vilotijević (2001) is of the opinion that this particularly refers to the students' eyesight and proposes that, "Letters must be large enough for a student to see them clearly at a $20 \mathrm{~cm}$ range. The spacing between the lines should be even and justified. Titles and subheadings should visually suggest a specific theme and its parts“ (Vilotijević, 2001: 421). Furthermore, the type of textbook material and paint used for printing should also be taken into account to avoid any damage to the health of the students using the textbook. Given that even very young students are forced to use and carry a growing number of textbooks and handbooks every day, the size and weight of a textbook should also be considered.

3. Meeting the above criteria in the process of making a contemporary textbook will not in and by itself result in the textbook fulfilling all of its functions. The use of textbooks for classes is "in close connection with the creative efforts of a teacher" (Slatina, 1998: 137). The teachers' creative efforts should entail them showing the students how to best use their textbooks in order to learn to combine them with other sources in a modern multimedia environment. ${ }^{5}$

Teachers must not transfer any of their basic functions as 'creators' and leaders of courses to textbooks, i.e. teachers cannot base all stages of the education process (from planning, through implementation to assessment) exclusively on textbooks. Quite on the contrary, a textbook must be used in the best possible manner throughout the stages taking into account the set output and objectives of the teaching process. "Textbooks cannot become cushions against the method inertness and indifference of teachers. Teachers are the factor ensuring that textbooks are compliant with other sources of their students' knowledge. Different methods involve different functions and purpose of a textbook" (Slatina, 1998: 137). Therefore, in the process of designing a textbook, the authors should take into account the fact that textbooks are not "packages of pre-made knowledge" but an important and not the only teaching aid in the education process. Regardless of all changes and transformations resulting from development of information technology and social relations overall, this aid will remain one of the main sources of knowledge for classes.

\footnotetext{
${ }^{5}$ For details refer to: Matijevic, M. (2004) Udžbenik u novom medijskom okruženju (Textbooks in the New Media Environment) In: Halačev, S. (ur.) Udžbenik $i$ virtualno okruženje (Textbooks and the Virtual World), Zagreb: Školska knjiga, pg. 73-82, as well as to: Matijevic, M. (2005) Novo medijsko okruženje i multimedijska didaktika (New Media Environment and Multimedia Didactics) In: Grandic, R. (ur.) Savremene koncepcije, shvatanja i inovativni postupci $u$ vaspitno-obrazovnom i nastavnom radu i mogućnosti primene u savremenoj školi (The Modern Concepts, Understandings and Innovative Approaches to Pedagogical-Educational and Teaching Activities, and Types of Preparation in A Modern School), Novi Sad: Savez pedagoških društava Vojvodine, pg. 338-350.
} 


\section{Conclusion}

Textbooks have always been and always will be one of the basic and main teaching aids, which is why such special attention has been paid to their design process. Today, the process is even more important than ever. Modern age requires constant reassessment of the basic pedagogical criteria and determinants for production and use of textbooks. The pedagogical determinants for production and use of textbooks are based on the very essence of classes and how they defer from all other aspects of the pedagogical-educational process. Hence, the production of textbooks is always directly conditional upon curriculum for particular types and levels of schools and the objectives and results of classes, both of which imply that the process of drafting a textbook must involve appropriate didactic, graphic design, linguistic, health-hygienic formatting; as well as upon the role of textbooks in selection of teaching methods and the set up of classes. Creating textbooks and defining the criteria a textbook must meet will be of importance at all times and for every educational system as the issue, given its significance and substance, cannot depend on pre-made solutions. High quality education cannot exist without high quality classes, high quality classes cannot exist without high quality structure of the learning process, and the high quality teaching and learning processes cannot exist without high quality textbooks. Any effort to improve teaching and learning must involve the improvement of textbooks at all stages of an education process. There is no room for improvisation on the matter.

\section{Bibliography}

Delors, J. (1998), Učenje: blago u nama - izvješće UNESCO-u Međunarodnog povjerenstva za razvoj obrazovanja za 21. stoljeće, zagreb: Educa

Matijević, M. (2004), Udžbenik u novom medijskom okruženju , u: Halačev, S. (ur.) Udžbenik $i$ virtualno okruženje, Zagreb: Školska knjiga. Dostupno i na: http://bib.irb.hr/datoteka/ 166896.UDBENIK_U_MEDIJSKOM_OKRUJU2.doc.

Matijević, M. (2005), Novo medijsko okruženje i multimedijska didaktika, u: Grandić, R. (ur.) Savremene koncepcije, shvatanja i inovativni postupci u vaspitno-obrazovnom i nastavnom radu i mogućnosti primene u savremenoj školi, Novi Sad: Savez pedagoških društava Vojvodine.

Potkonjak, N., Šimleša, P. (ur.), (1989), Pedagoška enciklopedija 2, Beograd, Zagreb, Sarajevo, Titograd, Novi Sad: Zavod za udžbenike i nastavna sredstva

Slatina, M. (1998), Nastavni metod, Sarajevo: Filozofski fakultet

Slatina, M. (2005), Od individue do ličnosti - uvođenje u teoriju konfluentnog obrazovanja, Zenica: Dom štampe

Stevanović, M. (1998), Didaktika, Tuzla: R\&S

Vilotijević, M. (2001) Didaktika 3, Sarajevo: BH most 
Metodički obzori 7(2012)2

Pregledni rad

UDK: 371.671

Received: 11. 11. 2010.

\section{TEMELJNE DETERMINANTE IZRADE SAVREMENOG UDŽBENIKA}

Dr. sc. Adnan Tufekčić

Odsjek pedagogija - psihologija

Filozofski fakultet Univerziteta u Tuzli

e-mail: adnan.tufekcic@untz.ba

\section{Sa žetak}

Izrada i korištenje kvalitetnih udžbenika jedno je od najvažnijih pitanja obrazovnog sistema. Udžbenik je jedno od osnovnih nastavnih sredstava koje je determinirano nizom ključnih zahtjeva koji se moraju ispuniti pri samom njegovom kreiranju i osmišljavanju. U radu se, u tom smislu, analiziraju neke od temeljnih pedagoških determinanti izrade i upotrebe udžbenike u suvremenoj odgojno - obrazovnoj realnosti. Pri tome su posebno obrađeni problemi kao što su uvjetovanost udžbenika od nastavnih planova i programa, ostvarivanje teleološke funkcije udžbenika kroz didaktičko, grafičko - likovno i tehničko, jezično i zdravstveno - higijensko oblikovanje udžbenika. Osim toga kratko je istaknuto i pitanje primjene udžbenika u metodičkom kreiranju i oblikovanju nastave od strane nastavnika u kontekstu suvremenih pristupa nastavi.

Ključne riječi: udžbenik, suvremena nastava, didaktičko oblikovanje, grafičko - likovno oblikovanje, jezično oblikovanje, zdravstveno - higijensko oblikovanje, nastavnik 